Research Article

\title{
The Biology of the African Bonytongue Heterotis niloticus (Cuvier, 1829) from the Lower Niger River at Agenebode in Edo State, Nigeria
}

\author{
M. O. Agbugui ${ }^{\mathbb{D}},{ }^{1}$ H. O. Egbo ${ }^{\mathbb{D}},{ }^{2}$ and F. E. Abhulimen ${ }^{1}{ }^{1}$ \\ ${ }^{1}$ Department of Biological Sciences, Edo State University, Uzairue, Edo State, Nigeria \\ ${ }^{2}$ Department of Morbid Anatomy and Histopathology, Edo State University, Uzairue, Edo State, Nigeria
}

Correspondence should be addressed to M. O. Agbugui; agbugui.marian@edouniversity.edu.ng

Received 28 June 2021; Revised 8 September 2021; Accepted 13 October 2021; Published 31 October 2021

Academic Editor: Andrea Galimberti

Copyright ( $\odot 2021$ M. O. Agbugui et al. This is an open access article distributed under the Creative Commons Attribution License, which permits unrestricted use, distribution, and reproduction in any medium, provided the original work is properly cited.

\begin{abstract}
Background. The African bonytongue, Heterotis niloticus, is readily accommodated in the fresh water of the Niger River. It is available all year round with a large population of juveniles and adults due to its fast growth and versatile feeding habits. This commercial fish is a highly preferred source of food because of its high protein content and hardy flesh, thus forming a very important component in the diet of many Nigerians. It is highly valued because of its socioeconomic importance and benefits. Hence, this research is designed with the aim of studying the biology of the African bonytongue, Heterotis niloticus, and providing viable information about its importance in fish culture in order to make an available added variety of culturable and affordable fish species in Nigeria. Results. The oesophagus is a muscular organ that is short and distensible. The oesophagus leads to the gizzard-like stomach, a reddish bilobed organ that is muscular and tough. H. niloticus is an omnivorous macrophage detritor, consuming a wide variety of bottom-dwelling food items. The histology of the gastrointestinal tract reveals four conspicuous layers from the inside to the outside: mucosa, submucosa, inner circular layer and outer longitudinal layer of muscularis, and serosa. The presence of numerous mucus glands and longitudinal folds with a prominent columnar epithelium provides durable length or an extension of the gut mucus to aid lubrication and easy passage of food materials, protecting the mucosal epithelium from mechanical or chemical injuries arising from interactions with digestive tract contents or enzymes. In addition, the presence of absorptive cells helps in the absorption of valuable nutritive substances. Conclusions. The anatomy of the mouth and gut and the aforementioned histology are modified to accommodate the feeding habits. $H$. niloticus has a single ovary that rests on the right side of the fish; it is reproductively active as the flood plains rise and peaks at the peak of the rains, being a moderately fecund fish. The high fecundity is complemented with peaks of GSI observed during the months of September, October, and November, which reveals spawning periods. Hence, the aforementioned attributes of H. niloticus make the fish a viable fish species for culture.
\end{abstract}

\section{Background}

The African bonytongue, Heterotis niloticus, is a large fish that is widespread in many tropical rivers and freshwater lakes of western and central parts of Africa [1]. In Nigeria, it is distributed along with many freshwater bodies. This fish species is readily accommodated in the fresh water of the Niger River with a large population of juveniles and adults. This successful adaptation is attributed to abundant varieties of feed and food in the river that is complemented with a versatile mode of feeding which is primarily correlated to the type of alimentary canal and digestive processes [2-4]. Heterotis niloticus is an important fish species to the fisherfolk and residents along the Niger River. It is the only species in the genus Heterotis and family Osteoglossidae. This commercial fish is a highly preferred source of food because of its high protein content and hardy flesh, thus forming a very important component in the diet of many Nigerians. It is highly valued because of its socioeconomic importance and benefits. It has a high growth rate and is 
available all year round in large quantities and large sizes [5]. Recently, a decline was reported by $[3,6]$. It is readily preferred and sold smoked or dried.

Fish is an important source of nutrients and also serves as the main source of protein in many Nigerian families. It is also highly recommended by WHO [7] and WHO [8] for the growing and ageing population because of its less tough fibre and immediate digestibility as well as its richness in omega-3 fatty acids needed for good health and brain development in children. The current fishery (culture, production, and management policies) cannot however satisfy the ever-demanding population, hence the need for optimal production and propagation. H. niloticus is one of the promising species that can be used for culture. To achieve this maximally, a thorough study to obtain knowledge of the fish must be carried out. Hence, this research is aimed at studying the biology of the African bonytongue $H$. niloticus.

\section{Methods}

2.1. Study Area and Description. The Niger River is the longest river in West Africa discharging into the Atlantic Ocean in Nigeria. It rises up to $240 \mathrm{~km}$ and runs for $4180 \mathrm{~km}$. The river is known to harbor 36 families of freshwater fish and nearly 250 species of which 20 are found nowhere else on earth but Nigeria. From Lokoja, the lower part of the Niger River, the river runs through Agenebode-Ida to Forcados in Delta and Nun River in Rivers State and further. The river is clean and relatively clear. The Niger River floods yearly beginning from September and peaks in November to January. Agenebode is located at latitude 7.10512 and longitude 6.69381 and stretches through an area of $1133 \mathrm{~km}^{2}$ (Figure 1). Agenebode waterfront is a very busy part of the Niger located in Edo State, Nigeria, serving water for domestic and industrial uses. Active fishing activities take place along the river for subsistence and commercial fishing.

2.2. Collection of Specimens and Sampling. One hundred and twenty-five (125) fish specimens were collected fortnightly for 12 months from November 2019 to October 2020 from three stations (based on the landing sites of fishing localities) from catch landings of fisherfolk by the use of canoes, gill nets, cast nets, drag nets, fish traps, and calabashes from the Lower Niger River at Agenebode. Fishes were transported to the Laboratory of the Department of Biological Sciences, Edo State University, Uzairue, Edo State. Fishes were rinsed; wiped; identified to species level using guides, keys, and pictures provided by [9-11]; and then preserved in $5 \%$ formalin.

2.3. Morphological Parameters. The standard length $(\mathrm{cm})$, total length $(\mathrm{cm})$, head length $(\mathrm{cm})$, gape mouth $(\mathrm{cm})$, girth, and weight $(\mathrm{g})$ of $H$. niloticus were obtained using a graduated ruler and tape, a measuring board, and a digital electronic scale (Sartorius 177). These were recorded and analyzed. Fin counts and measurements were also taken and recorded.
2.4. Anatomy and Histology. Twenty samples of H. niloticus comprising different sizes (length and weight) were used. The mouths and intestinal tracts were removed. The oesophagus, stomachs, and intestines were gently slit open. Their content was rinsed off in gently flowing tap water and thereafter fixed in $10 \%$ formaldehyde. The samples were then dehydrated through a standard ethanol series to $100 \%$, cleared in xylene, embedded in paraffin wax, then sectioned with a rotatory microtome set at 5-6 pm, deparaffinized, and stained with hematoxylin and eosin. Prepared slides of the gastrointestinal tract were mounted and examined with Olympus Electronic Microscope (model Bino Cxi IS 4381) (PL120) to view and capture features of biological interest.

Pictures of the mouth, jaws, and pharyngeal teeth were taken with a digital Infinix camera (Model X650B).

2.5. Determination of Sex. Sex could not be obtained from external observation. The stomach was split open from the lower abdominal region to determine the sex. Sex was determined by visual and microscopic observation of the gonads. A fish with one ovary was referred to as female, while a fish with no ovary was referred to as male.

2.6. Length-Weight Relationship (LWR). The total length (TL) and body weight $(W)$ were measured in the fresh samples to the nearest $0.1 \mathrm{~cm}$ and $0.01 \mathrm{~g}$, respectively. The length-weight relationships were estimated from the formula $W=a L b$, where $W$ is the total body weight $(\mathrm{g}), L$ is the total length $(\mathrm{cm})$, and $a$ and $b$ are the coefficients of the functional regression between $W$ and $L$. This relationship was transformed into a linear form by the following equation:

$$
\log W=\log a+b \log L
$$

2.7. Condition Factor. The condition factor $K$ was calculated by the following formula given by [12]

$$
\frac{(K=100 W)}{L^{3}},
$$

where $W$ is the total weight of fish in grams, $K$ is the condition factor, and $L$ is the total length of fish in centimeters. It was calculated for each sex separately and then for the combined sexes. Variations of $K$ with season and size groups were also determined.

2.8. Gonadosomatic Index (GSI). The gonadosomatic index of samples of $H$. niloticus was determined according to Ugwumba et al. [13] as follows:

$$
\text { GSI }=\frac{\text { weight of gonad } \times 100}{\text { weight of fish }} \text {. }
$$

The monthly catches were sorted by sex. The mature female ovaries were analyzed and used to determine the GSI. 


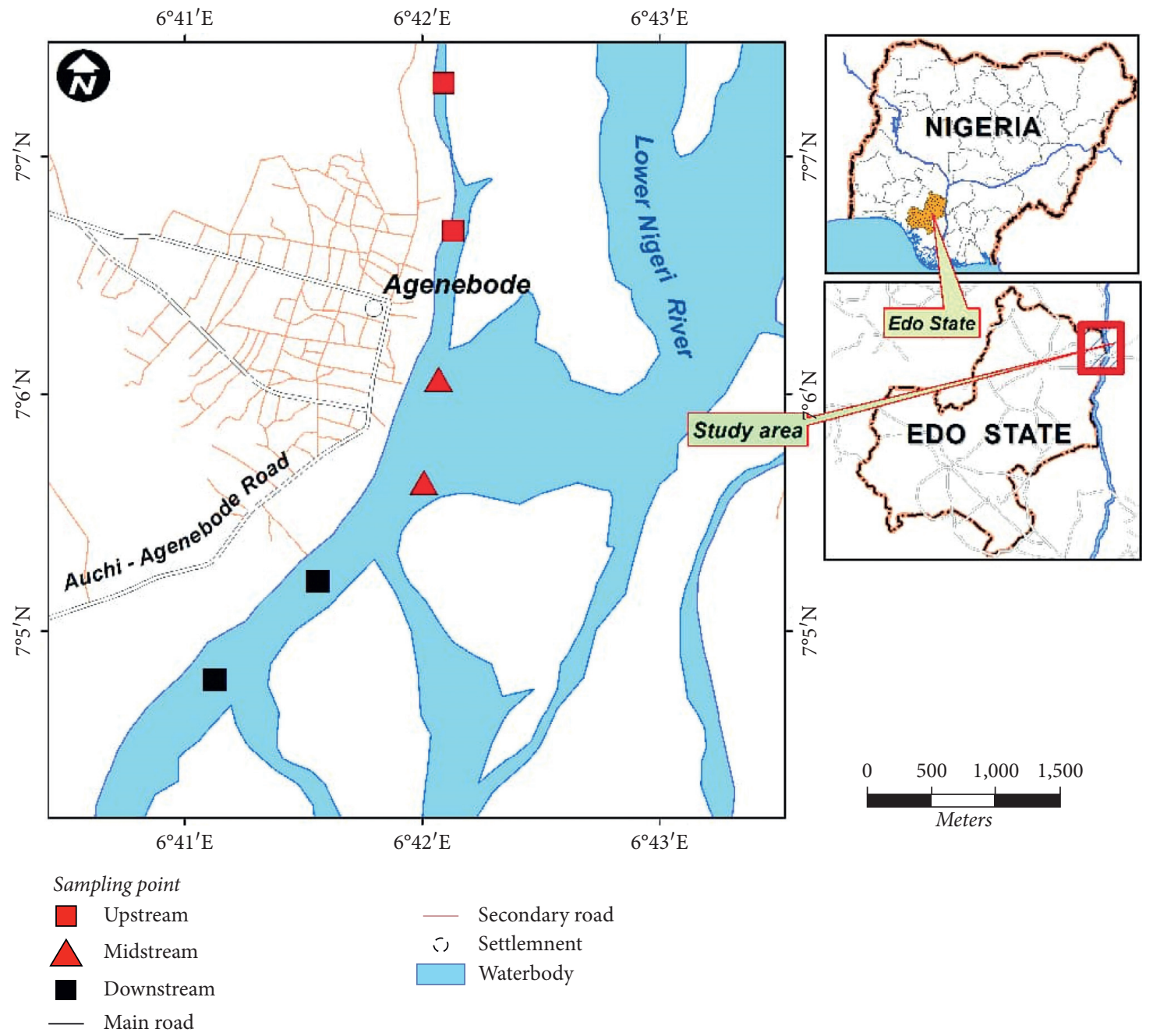

Figure 1: Map of the Lower Niger River showing study sites.

Fecundity: the ovary of the mature fish was removed and placed gently in boiling water and allowed to boil for 20 minutes. The eggs became hard enough for easy counting. The boiled eggs were then stored in $5 \%$ formalin. $1.00 \mathrm{~g}$ of the whole ovary was cut off. The cut section of the eggs was carefully counted and multiplied by the total weight of the ovary to give the total number of eggs.

The maturity stages of the ovaries were classified according to Nikolsky [14]:

Stage 1, immature; Stage II, quiescent; Stage III, maturing; Stage IV, mature; Stage V, running; Stage VI, spent.

Egg diameter: egg diameter $(\mathrm{mm})$ was measured with an ocular micrometer. A stage micrometer was earlier used to calibrate the microscope. Diameters of twenty eggs randomly selected from each ovary were measured, and their mean was taken as the average egg diameter.
2.9. Determination of Food and Feeding Habits. Each stomach was split open, and the contents were emptied into a Petri dish. The contents were observed under a hand lens, and the food materials were identified.

Frequency of occurrence method (FO): in the frequency of occurrence method, the individual food matter in the stomach was sorted and identified. The number of stomachs in which each food item occurred was expressed as a percentage of the total number of stomachs with food examined.

Number of occurrence method (NO): this method involves counting the number of each food item present in the stomach of a fish and summing these numbers to obtain the total number of all food items found in the stomach. The number of each food item is then expressed as a percentage of the total number of all food items. It was expressed as 


$$
\text { percentage number of a food item }=\frac{\text { total number of a particular food item }}{\text { total number of all food items }} \times 100 \text {. }
$$

Index of relative importance (IRI): the importance of various food items was determined with the index of food importance following the method of Ugwumba and Ugwumba [15]:

$$
\mathrm{IRI}=(C n+C w) X F,
$$

where IRI is the index of relative importance, $C n$ is the percentage of numerical composition, $C w$ is the percentage of gravimetric composition, and $F$ is the percentage of frequency of occurrence.

The dietary compositions for the species examined were expressed as percentages; that is,

$$
\% \mathrm{IRI}=(C n+C w) X F \times 100 .
$$

A food item with $\%$ IRI $\geq 3$ is regarded as primary, $\geq 0.1$ to $<3$ secondary, and $\leq 0.1$ incidental.

The relative gut length (RGL): this was expressed as the ratio of the total length of the gut to the total body length [16].

$$
\mathrm{RGL}=\frac{\text { total length of gut }}{\text { total length of fish }}
$$

where fish can be classified as herbivorous (RLG $>1$ ), carnivorous $(\mathrm{RLG}<1)$, or omnivorous $(\mathrm{RLG}=$, or $>$, or $<1)$.

Prey-predator relationship: the relationship between the total body length and the total weight of Heterotis niloticus and prey body weight was determined and described by the following equation [17]:

$$
Y L=a+b \times L
$$

where $Y L$ is the prey's body weight $(\mathrm{g})$ and $L$ is the predator's body length $(\mathrm{cm})$ or body weight $(\mathrm{g})$.

2.10. Statistical Analyses. The data obtained from this study was used to derive the means and standard deviation. Linear equations were also used to derive linear regression in the Microsoft Excel 2010 statistical package. Other statistical formulae were given and applied using Microsoft Excel 2010 for analyses.

\section{Results and Discussion}

Heterotis niloticus is bronze in color, elongate, compressiform, and covered with strong large cycloid scales. The retractable mouth is terminal with thick lips. In this study, the largest fish species obtained was $64 \mathrm{~cm}$ long with a weight of $2787 \mathrm{~g}$ (Figure 2). The dorsal fins are situated towards the posterior of the fish with 33-38 rays, the pectoral fins are paired with no spine and 12 rays, the pelvic fins are paired with no spine and 6 rays, and the anal fin consists of 35 rays.
The African bonytongue has 5 rows of scales above the lateral line and 6 below the lateral line, in addition to $48-52$ scales on the lateral line. The formula of fin count is thus D33-38: P12: V6: A35-38: C13-15 (48-52(6/8)). These meristic characteristics, number and shape of fins, are often used in the identification of this fish species. The fin count obtained in this study corresponds with other identifications by $[10,18]$.

The mouth opens up to $8 \%$ of the total body length making room for numerous and large number of small food materials to be taken in at once (Figures 2 and 3). Its nuchal region is humped; its depth is 3.5-5.0 times its height; its head is short, $3.3 \%$ of the total length; the gill openings are covered by a bony operculum that ends with a fleshy attachment, one visible lateral line; and the eyes are sunken and golden brown. The composite anatomy of the interior of the mouth is cartilaginous; this is probably because of its kind of feeding specifics or preference for bone food species or cartilaginous ones, organisms with some form of a skeleton. In the mouth, the tongue is very thick, sort of cartilaginous; this hard nature of the tongue might be an added reason for its name (bonytongue). Behind the tongue is the pharyngeal palate with pebble-like teeth; these palates with teeth are on the roof and floor of the mouth.

The sides of the mouth overlap to give room for extensions. The tongue is very thick and cartilaginous and has teeth on the posterior end.

There are 5 gills on each side. These gills are folded to extend to the roof of the mouth (Figures 4 and 5). The third has forked cartilage attached to it that extends to the pharyngeal palates. Each gill has a very thick cartilaginous arc, long and slender rakers (178-206), and pairs of filaments (82-86 pairs) which are perfect for sieving tiny food particles such as detritus. Attached to the gills are a pair of the bulblike sacs that are made of an internal anal filled with yellow matter suspected to be used for balancing or as an olfactory organ (Figure 5). The teeth on the jaws are few and not prominent. Cardiform teeth are present on the premaxilla and dentine and are premandibular.

The oesophagus is a muscular organ that is short and distensible. The oesophagus leads to the gizzard-like stomach, a reddish bilobed organ that is muscular and tough (Figure 6). This species has frequently been characterized either as an omnivore, insectivore, or detritor, with the latter being, in part, because of its benthic feeding habitats and possession of a gizzard (thick-walled pyloric stomach). This organ is often filled with fluid and not seeds or stones as in the case of birds, and this is also in conformity with the report of [19]. The pyloric ceca are from the end of the gizzard, consisting of two long tubular extensions (17\% of the total length of the fish). The function of the pyloric ceca of fish has been postulated as an organ "to store up the food," "putrefy it up," and "concoct it" that is (storage, fermentation, and digestion). Buddington and Diamond [20] reported that the trout, cod, largemouth bass, and striped have 


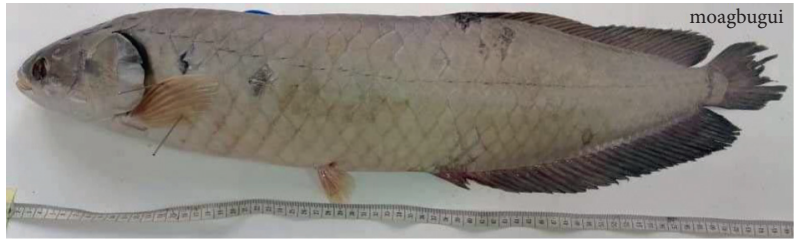

FIgURE 2: The body of Heterotis niloticus.

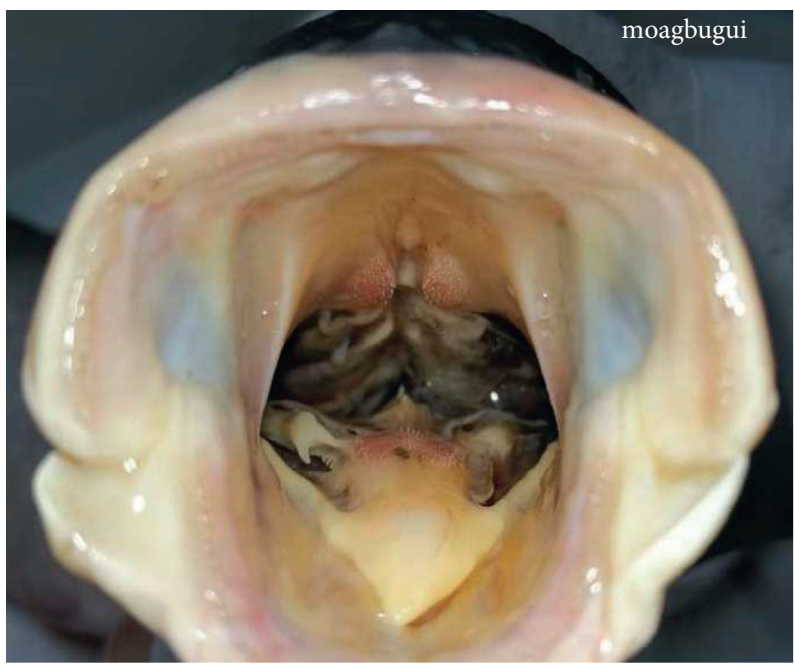

Figure 3: The gaping mouth of Heterotis niloticus, opening up to $12 \%$ of the total body length.

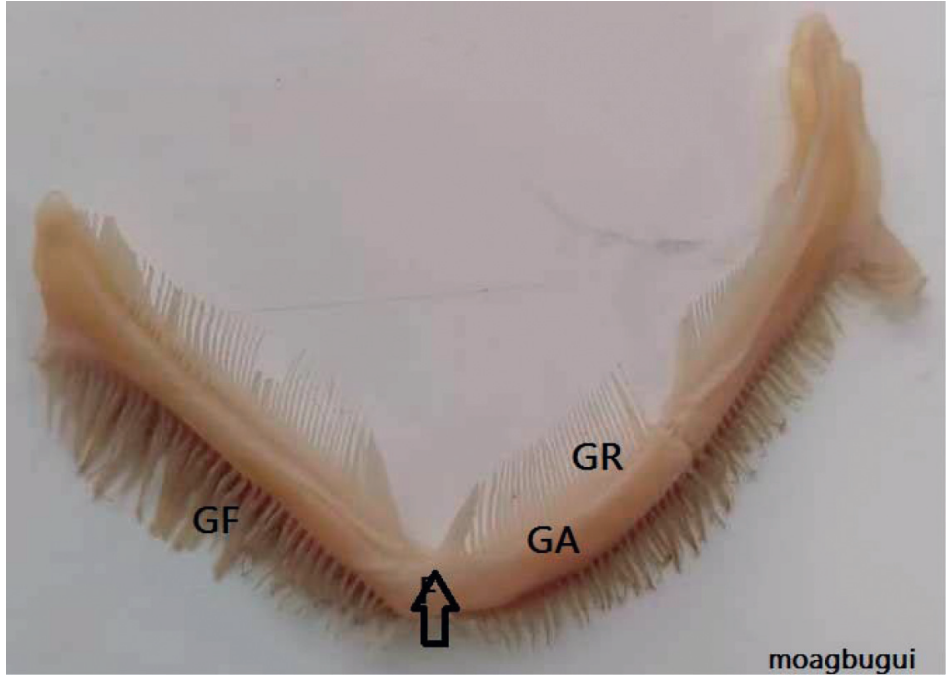

Figure 4: One gill of H. niloticus. GR, gill rakers; GF, gill filament; GA, gill arc. The arrow shows area where the gill folds to extend to the roof of the mouth.

pyloric ceca which assist in the digestion of food materials. Further studies showed the presence of enzymes, and the ceca proved to be a major site of sugar, amino acid, and dipeptide uptake, contributing more uptake than the entire remaining alimentary tract in trout and codfishes. The presence of carbohydrates has been reported in the stomach and pyloric ceca of the African bonytongue; this is an indication that ample digestion of carbohydrate materials takes place at this organ site [21].
The intestine also arises from the gizzard and can be clearly distinguished into two sections: the small intestine and large intestine; this organ is very long measuring up to $119 \%$ of the whole fish. The intestine ends with the cloaca (Figure 7). This gut length is an indication of herbivorous or omnivorous species. Fishes with long intestines that are more than $100 \%$ of their length is often either herbivorous or omnivorous. The length of the intestine gives room for digestion of the food materials ingested. 


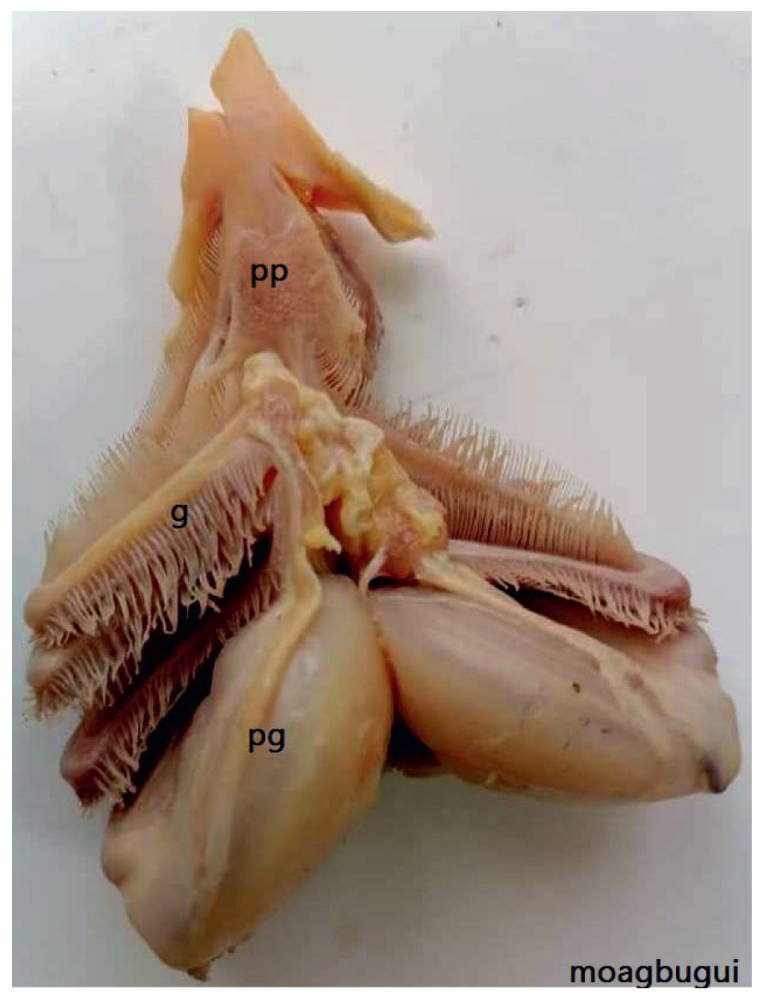

FIGURE 5: Gill of H. niloticus. pp, pharyngeal figure showing teeth; $\mathrm{g}$, gills; pg, pouch of gills.

The bilobed liver is large and lies over the gizzard stomach. The bile duct and pancreas lie above the gizzard, and the intestines are sheathed in fat, intestinal lining, and serosa.

Four major and distinct layers make up the gut of $H$. niloticus which is typical of higher vertebrate animals. The oesophagus composed of four conspicuous layers from the inside to the outside: mucosa, submucosa, inner circular layer and outer longitudinal layer of muscularis, and serosa (Figure 8(a)). The mucosa showed large numbers of the esophageal folds of the lumen of the oesophagus giving ovalshaped appearance in all sections. These oval folds were thick and elongated and had few gastric glands. The serosa is distinct, and these longitudinal folds may lead to an increase in the capacity of the organ for distension during food transportation [22]. The stomach of $H$. niloticus (Figure 8(b)) showed dense regions of the gastric gland revealing gastric cells within stratified epithelial cells. The mucosa of the stomach consists of surface and gastric epithelium. The surface epithelium is made up of a single layer of columnar epithelial cells, and the gastric epithelium consists of gastric glands. The lamina propria, in the form of a connective tissue network, lies between the gastric glands. The muscularis consists of an outer longitudinal and an inner thick circular muscle layer. The columnar epithelium was filled with lamina propria and mucus-secreting cells. The mucous secreted by these cells may be attributed to the lack of salivary glands in fishes; however, reports revealed that mucin is secreted by the esophageal epithelium which is probably a compensation $[23,24]$. Furthermore, the mucin

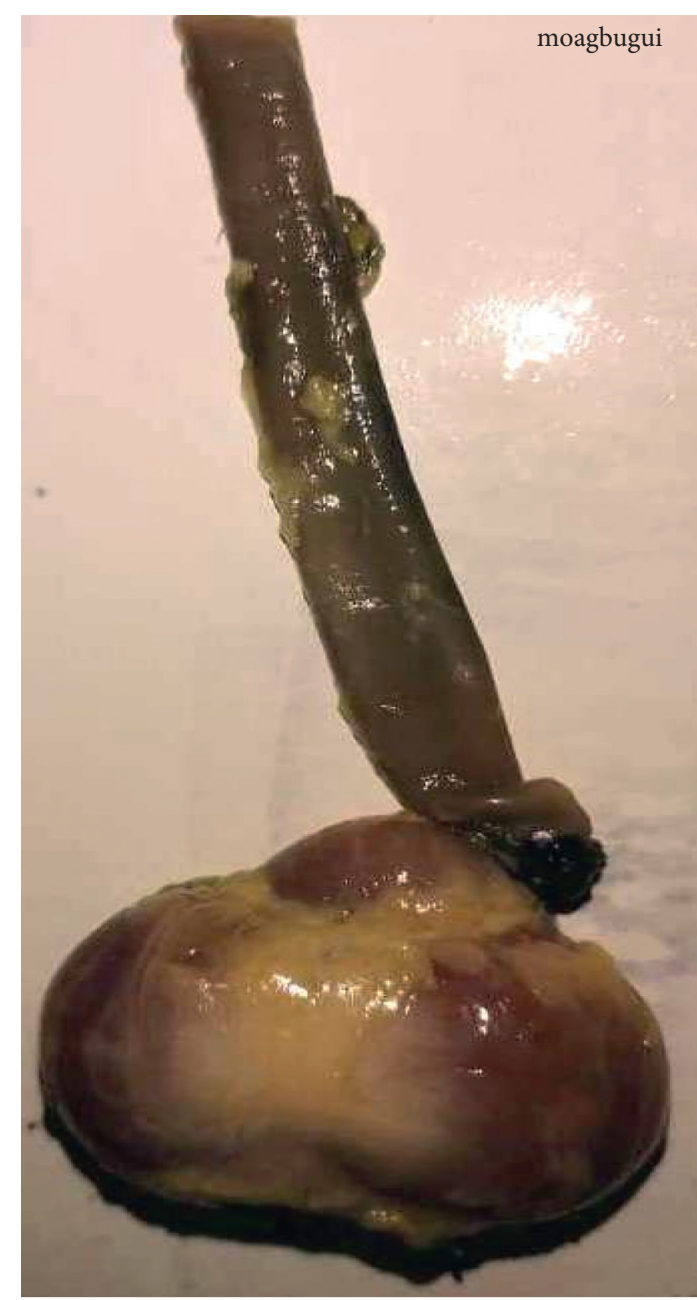

Figure 6: Gizzard-like stomach of $H$. niloticus.

and mucus secretions are important for the formation of a continuous sheet along the entire wall of the oesophagus, lubrication of food particles, ionic absorption, and protection of the esophageal mucosa against mechanical damage and bacterial invasion, while mucous secretions participate in enzymatic digestion of the ingested food and facilitate its transformation into chime $[25,26]$.

The pyloric ceca (Figure 8(c)) had a dense muscularis, the mucosa had flat epithelium filled with cells, and gastric pits and mucus glands were not visible. The absence of glands and pits with visible macrovilli in the pyloric ceca reveals that this organ is not essential for digestion. Its location between the stomach and the intestine could be primarily to store food and slow down the passage of food into the intestine, providing enzymes and digestive abilities for food. Carnivorous fish species are known to have short intestine, hence the presence of other organs to assist in digestion. The stomach is composed of numerous longitudinal folds, gastric glands, gastric pits, columnar striated epithelium, lamina propria, and microvilli making the function of the stomach specialized. These findings are in agreement with those of $[27,28]$. In this study, it was observed that the stomach muscularis possesses a circular layer 


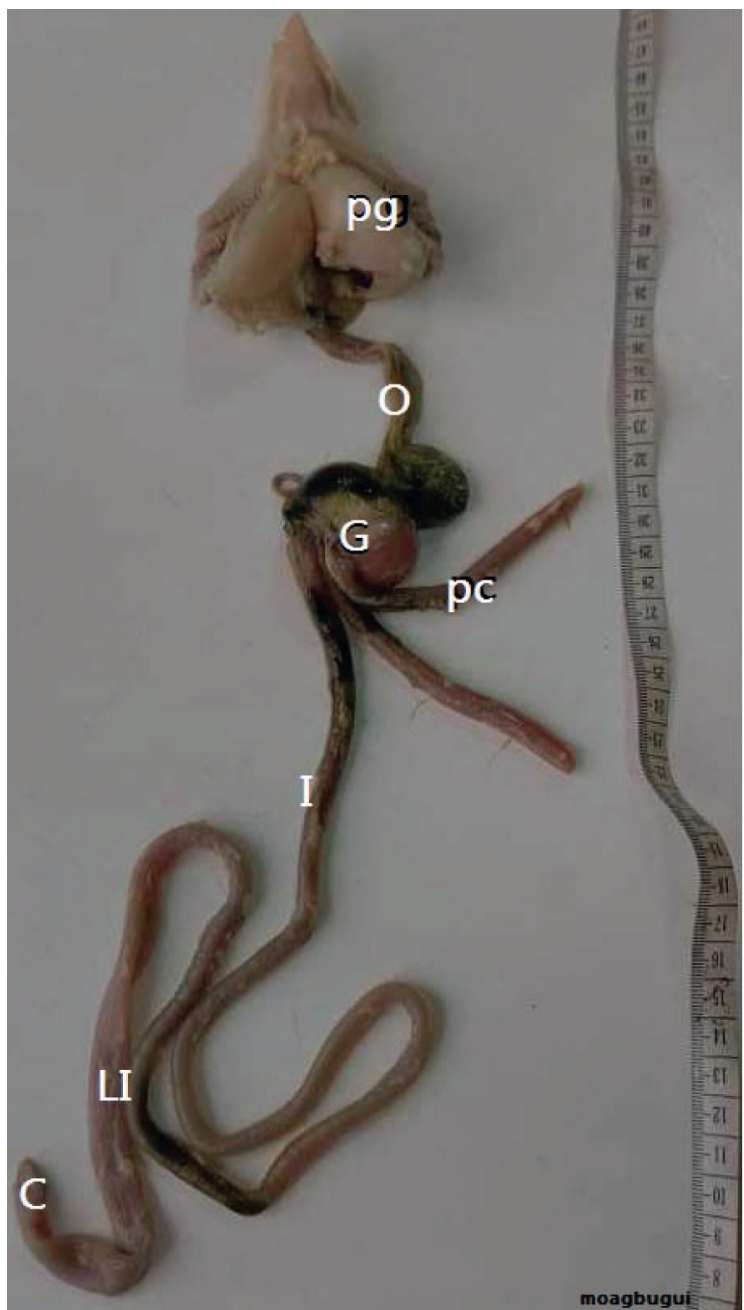

FIGURE 7: The detached GIT of H. niloticus. pg, pouch of gills; O, oesophagus; G, gizzard-like stomach; pc, pyloric ceca; I, intestine; LI, large intestine, C, cloaca.
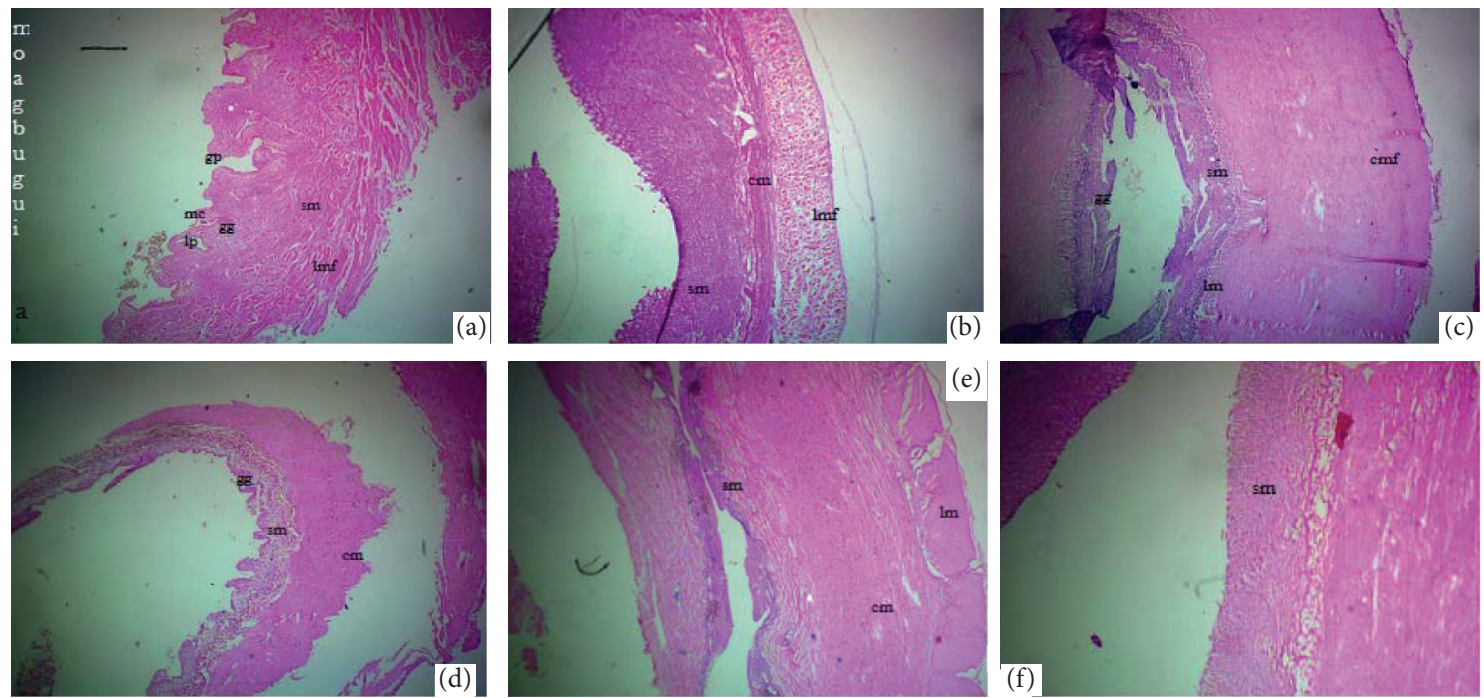

FIGURE 8: Histology of the gastrointestinal tract of H. niloticus: (a) oesophagus; (b) stomach; (c) pyloric ceca; (d) small intestine; (e) large intestine; (f) cloaca. gg, gastric gland; sm, submucosa; gp, gastric pits; lp, lamina propria; mc, mucus cells; cmf, circular muscle fibre; lmf, longitudinal muscle fibre. 
that is thicker than the longitudinal layer, which is consistent with the findings of $[22,26,29]$. The small intestine, which is the anterior section of the intestine, showed numerously mucus glands; the mucosa revealed longitudinal folds of finger-like projections (villi), with a prominent columnar epithelium; and the macro- and microvilli possess cells that line the entire length of the intestine. The provision for excess mucus gland aids lubrication and easy passage of food materials, protecting the mucosal epithelium from mechanical or chemical injuries arising from interactions with digestive tract contents or enzymes, and the presence of absorptive cells helps in the absorption of valuable nutritive substances. The villi help to absorb nutrients from the food eaten and then shuttle the nutrients into the bloodstream of every species [30-32]. The posterior region which is the large intestine shows gastric pits and glands, the mucosal folds are numerous, and the presence of large villi is prominent. The columnar epithelium is distinct. The large intestine has a thick and dense circular muscle, the submucosa has very reduced gastric glands and gastric pits, the columnar epithelium and lamina propria are short (Figure 8(e)). The cloaca is packed with dense circular muscle and a reduced submucosa (Figure 8(f)). The cloaca is a region for reserving waste before it is passed off the gut. The cloaca has strong muscle for appropriate contraction to propel defecation.

Total weight and standard length of the 125 specimens of $H$. niloticus examined were within the ranges of 219-3417 g $(2148.06 \pm 715.93)$ and $21.0-98.0 \mathrm{~cm}(56.96 \pm 13.08)$, respectively Table 1 .

The Heterotis species are available all year round in large numbers. In this study, it was noticed that size was related to sex (Table 1). Using the mean and standard deviation, it was seen that female Heterotis species were larger than the males with a significant difference. A $t$-test was used to compare sex to size (length and weight). The result of the $t$-test of length and weight of females was 0.6 , while for males 0.1 was obtained. Females are possibly larger than males because of the tendency to acquire food in preparation for reproductive capacity, hence the need for extra capacity and the ability of the anatomy and body structure to accommodate reproductive organs. Furthermore, females could grow larger because they possibly eat more for extra energy during spawning, hatching, and care of young ones. The sexual abundance $(1: 1.5)$ in favor of the females in the Lower Niger River may be influenced by variable factors including food availability, short lifespan, rapid growth, and conducive environment. Variety of fish species in addition to other macro- and microinvertebrates is available all year round in the river, thus enabling rapid growth and high recruitment. The active survivors prey on the rich variety of food available in the river; they grow very fast and become recruited into the fishery.

The length-weight relationship (LWR) of Heterotis niloticus obtained in the study for the whole population (both males and females) revealed a correlation coefficient $(r)$ of 0.83 as shown in Table 2.

The value obtained for $b$ was 0.53 for the whole population, 0.41 for males, and 0.26 for females. This result shows that $H$. niloticus exhibits a negative allometric growth
TABLE 1: Summary of length and weight parameters of $H$. niloticus.

\begin{tabular}{lccccc}
\hline Males & $\begin{array}{c}\text { Length } \\
(\mathrm{cm})\end{array}$ & $\begin{array}{c}\text { Weight } \\
(\mathrm{g})\end{array}$ & Females & $\begin{array}{c}\text { Length } \\
(\mathrm{cm})\end{array}$ & $\begin{array}{c}\text { Weight } \\
(\mathrm{g})\end{array}$ \\
\hline Min & 21 & 246 & Min & 25 & 219 \\
Max & 77 & 2952 & Max & 98 & 3417 \\
Total & 2400 & 96663 & Total & 4443 & 172555 \\
Average & 53.33333 & 2148.067 & Average & 56.96154 & 2212.244 \\
SD & 10.91788 & 715.9376 & SD & 13.08105 & 707.1197 \\
$N$ & 36 & & $N$ & 53 & \\
Df & 35 & & Df & 52 & \\
\hline
\end{tabular}

TABLE 2: Linear relationship of morphometric parameters of Heterotis niloticus.

\begin{tabular}{|c|c|c|c|c|c|}
\hline \multicolumn{2}{|l|}{ Population } & $a$ & $b$ & $R^{2}$ & $r$ \\
\hline \multicolumn{6}{|l|}{$L W R$} \\
\hline \multicolumn{2}{|l|}{ Whole population } & 1.645 & 0.532 & 0.683 & 0.83 \\
\hline \multicolumn{2}{|l|}{ Males } & 1.891 & 0.041 & 0.693 & 0.83 \\
\hline \multicolumn{2}{|l|}{ Females } & 1.745 & 0.263 & 0.663 & 0.83 \\
\hline \multicolumn{6}{|c|}{ Length-girth relationship (LGR) } \\
\hline \multicolumn{2}{|c|}{ Whole population } & 0.995 & -0.236 & 0.661 & 0.77 \\
\hline \multicolumn{2}{|l|}{ Males } & 0.921 & -0.341 & 0.633 & 0.78 \\
\hline \multicolumn{2}{|l|}{ Females } & 01.11 & 0.256 & 0.692 & 0.69 \\
\hline \multicolumn{6}{|l|}{ Condition factor $(K)$} \\
\hline Whole population & 1.51 & & & & \\
\hline Males & 1.87 & & & & \\
\hline Females & 2.14 & & & & \\
\hline
\end{tabular}

$(b<3.0)$ meaning that the length increases much more with body weight. This finding is in line with those of $[33,34,35]$. The length-girth relationship of $H$. niloticus showed a strong and positive correlation coefficient $(r)$ of 0.77 . The mean condition factor $K$ was 1.51 ( $t$-test, $P>0.05$ ), which indicates that the Heterotis are in good condition in the river. Many factors could determine the productivity of a river; availability of food, proper management policies, pollution, turbidity, and indiscriminate dredging could affect the condition and production of the river. Moreover, heavy bodied fishes such as the Heterotis species are noted to have higher condition factors than those with flattened bodies [36]. It is also reported that $H$. niloticus can thrive well in polluted and turbid waters, hence its ability to maintain a condition factor $>1[37,38]$. Out of the 125 specimens obtained, 36 were males while 53 were females with a ratio of $1: 1.5$, and the remaining 36 were unsexed. All of these specimens were examined for variety of food items; 69 had empty stomachs while 56 had food items in their stomachs. The percentage composition of food items obtained from H. niloticus from November 2019 to October 2020 is shown in Table 3.

The dominant food items found were copepods (33.48\%) and shrimps (16.74\%) by \%FO. Other food items of low importance were mollusc, plant parts, sand, and detritus: $14.16 \%, 12.02 \%, 3.43$, and $14.59 \%$, respectively (Table 3 ). The food item with the most relevance was copepod with a percentage of $34.45 \%$.

The food items obtained in this study from the stomachs of $H$. niloticus show a dominance of arthropods and crustaceans in addition to detritus materials, suggesting frequent 
TABLE 3: Percentage composition of various food items consumed by Heterotis niloticus.

\begin{tabular}{lccccc}
\hline Food items & \%NO & \%FO & \%W & IRI & \%IRI \\
\hline Copepods & 35.42 & 33.48 & 43.71 & 0.34 & 34.45 \\
Shrimps & 18.75 & 16.74 & 14.22 & 0.18 & 17.74 \\
Mollusc & 7.64 & 14.16 & 16.85 & 0.11 & 10.90 \\
Plant parts & 8.33 & 12.02 & 6.74 & 0.10 & 10.18 \\
Sand & 5.56 & 3.43 & 2.69 & 0.04 & 4.49 \\
Fish & 7.64 & 5.58 & 10.01 & 0.07 & 6.61 \\
Detritus & 16.67 & 14.59 & 5.79 & 0.16 & 15.63 \\
Total & 100 & 100.00 & 100.00 & 1.00 & 100 \\
\hline
\end{tabular}

NO: numerical method, FO: frequency of occurrence method, $W$ : gravimetric method, IRI: index of relative importance. Food items with \%IRI $>3$ are regarded as primary and $>0.1$ to $<3$ are secondary, whereas those with \% IRI $<0.1$ are considered as incidental food items.

bottom feeding on benthic invertebrates as shown in Table 3 . It is evident that $H$. niloticus was strictly a planktonic microphage. Larger fish had some whole fish or sometimes fish flesh in their stomach. The presence of plant remains and sand could be due to the probability that while grazing on other benthic organisms it scraped, quickly pulled out, or nipped off plants along with their substrate. Hence, the variation of food items, which include sand, detritus, fish, copepods, shrimps, and mollusc, makes it possible to conclude that $H$. niloticus is an omnivore. From the shape of the mouth and the arrangement of the gills, it could be concluded that filter-feeding habit is made possible by the possession and arrangement of fine gill rakers and gill filaments as seen in Figures 4 and 5 . Although the species had earlier been described as more of a plankton feeder $[11,39]$, this study has shown that $H$. niloticus is an omnivore with arthropods and crustaceans being the significant food items in its diet with the capability of filtering planktons and other food substances in water. Similar findings proving that $H$. niloticus is an omnivore were reported by [34, 39-41]. The nature of the gut, possession of a gizzard (food grinder), and long gut length (extended absorption) of the intestine are important features that show omnivorous feeding. The gizzard serves as an organ of digestion. Fluid and digested matter were preset in the gizzard with no grains or seeds as in the case of birds. The gut length recorded in this study (mean of $77.32 \mathrm{~cm}$ ) and the relative gut length (RGL) of 1.08 suggest a long gut transit time for the food of this fish. According to Biswas [16], fish can be classified as herbivorous (RLG $>1$ ), carnivorous ( $R L G<1$ ), or omnivorous $(R L G=$, >, or $<1$ ). With regard to the RGL, the result obtained in this study shows that $H$. niloticus is a herbivore, but the food items discovered do not show that. Following the theory of WardCampbell and Beamish [42] which is supported by [43-46], it is generally accepted that $\mathrm{RGL}<1$ indicates carnivorous diet, and $\mathrm{RGL}<3>1$ indicates omnivorous, whereas values of RGL '3 indicate diet based on plant material or detritus. This theory is an added proof that H. niloticus is an omnivore.

In this study, the prey-predator relationship of H. niloticus revealed that fish weight was more related to prey size as shown in Figures 9 and 10.

A linear and positive relationship between the predator body weight and prey body weight of $H$. niloticus was observed. Larger prey was obtained as the fish size (weight)

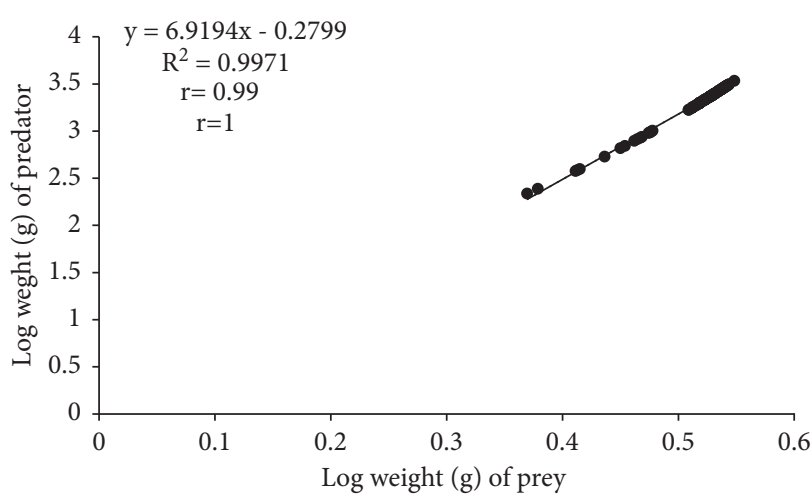

FIGURE 9: Relationship between prey body weight and total weight of Heterotis niloticus.

increased. A perfect relationship between the weight of $H$. niloticus and its prey was obtained. This shows that as the fish gets bigger, larger sizes of meals were preferred to smaller ones; hence, size of fish is associated with feeding capacity. Similar findings relating feeding capacity to size were reported by [47-52].

Heterotis niloticus possesses a single ovary located on the right side. Color of ovary is amber or ovary pink at the quiescent/immature stage, deep pink in mature stages, and yellow to orange in mature and running stages. The ovary is elongated and larger at the anterior part and thinner at the posterior end towards the cloaca, laterally compressed, and has 51-82 \pm 68 lamellar folds. H. niloticus showed variation in gonadosomatic index (GSI) which was greatly induced by season and size of fish. Monthly averages of GSI were recorded in the rainy season with its peak in the months of May to September and then a decrease till November. No gravid females were found in November till early February, which confirms that the spawning period begins as the flood plains rise in the rainy season. The African bonytongue has relatively large eggs $(2.3 \mathrm{~mm}-3.00 \mathrm{~mm})$ and moderate fecundity (2100-32000 eggs) (Table 4). The size of H. niloticus in the Lower Niger River at first maturity was not calculated in this study because the size of sample collected is small $(<500)$.

The number and size of eggs were dependent on the size of fish. The weight in relation to its length was a determinant for ovarian weight and oocyte count available to a species. Mature fishes represented gonad stages of 2-5. Mature fishes were recorded from fish with sizes of $368 \mathrm{~g}-2000 \mathrm{~g}$. The smallest mature fish observed has a TL of $31 \mathrm{~cm}, S L$ of $21 \mathrm{~cm}$, and $W$ of $368 \mathrm{~g}$, with the length of the gonad being $5.3 \mathrm{~cm}$ and weight being $5 \mathrm{~g}$. Fecundity was obtained only for 19 fecund female specimens.

Six stages of gonad development were found in $H$. niloticus during the sample period in both males and female fishes: the immature, quiescent, maturing, mature, running, and spent stages (Table 5).

The decline in rainfall which correlated to reduction and absence of gravid females suggests the end of spawning periods. The changes in GSI revealed that $H$. niloticus has specific periods for maturation of ovaries, spawning, and breeding times. $H$. niloticus is thus observed to be 


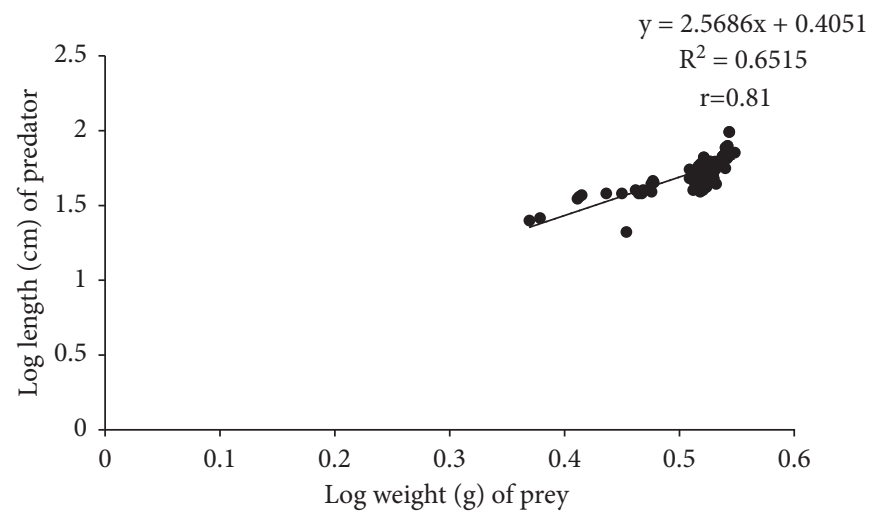

FIGURE 10: Relationship between prey body weight and total length of Heterotis niloticus.

TABLE 4: Summary of gonadosomatic index (GSI) of Heterotis niloticus.

\begin{tabular}{lcc}
\hline Parameters & Males & Females \\
\hline Sample size $(n)$ & 36 & 53 \\
Total length $(\mathrm{cm})$ & 515.00 & 4139.00 \\
Mean \pm SD & $57.22 \pm 7$ & $59.13 \pm 11.0$ \\
Total weight $(\mathrm{g})$ & 20635.00 & 166456.00 \\
Mean \pm SD & $2292.78 \pm 566.58$ & $2377 \pm 515.3$ \\
Mean gonad weight (g) & $26.89 \pm 8.0$ & $23.90 \pm 7.52$ \\
Gonadosomatic index (GSI) & $1.29 \pm 1.22$ & $1.00 \pm 1.56$ \\
Fecundity $(n)$ & $\mathrm{Nil}$ & $21548 \pm 6065.33(19)$ \\
\hline
\end{tabular}

TABLE 5: Stages of gonad developments observed in H. niloticus.

\begin{tabular}{|c|c|c|}
\hline \multirow{2}{*}{ Gonad stage } & \multicolumn{2}{|r|}{ Macroscopic character } \\
\hline & Testis & Ovaries \\
\hline $\begin{array}{l}\text { (I) } \\
\text { Immature }\end{array}$ & Not encountered & Not encountered \\
\hline $\begin{array}{l}\text { (II) } \\
\text { Quiescent }\end{array}$ & Testis were small and opaque in color & $\begin{array}{l}\text { The quiescent stage had ovaries that were translucent and pinkish in color, } \\
\text { oocytes were not visible to the naked eye, and blood vessels were seen on the } \\
\text { surface of ovaries }\end{array}$ \\
\hline $\begin{array}{l}\text { (III) } \\
\text { Maturing }\end{array}$ & $\begin{array}{l}\text { The males had small milt that was milky in } \\
\text { color }\end{array}$ & $\begin{array}{c}\text { The maturing stage had ovaries that were creamy in color; oocytes could be } \\
\text { visible though not well developed }\end{array}$ \\
\hline (IV) Mature & $\begin{array}{l}\text { The mature stage had larger milt that could be } \\
\text { released with some pressure }\end{array}$ & $\begin{array}{c}\text { There were creamy colored eggs with visible oocytes that could be counted. } \\
\text { Blood vessels were very visible }\end{array}$ \\
\hline $\begin{array}{l}\text { (V) } \\
\text { Running }\end{array}$ & Milt could be released with little pressure & Eggs could be released with little pressure \\
\hline (VI) Spent & Not encountered & Not encountered \\
\hline
\end{tabular}

moderately fecund ((2100-32000 eggs) when compared to fish species like the African mudfish (Protopterus annectens) and the grunt (Pomadasys jubelini) $[2,53]$. These results are in conformity with the findings of [19]. This study reveals an overlap in the ranges of average sizes in relation to maturity stages. This could be because $H$. niloticus does not depend on length alone but also weight of the fish and other contributing factors such as availability of food, water quality, climate changes, and neural responses [54-58].

\section{Conclusion}

Heterotis niloticus is an omnivorous macrophage detritor, consuming a wide variety of bottom-dwelling food items. The anatomy of the mouth and gut along with its histology is modified to accommodate the feeding habits. H. niloticus has a single ovary which rests on the right side of the fish; it is reproductively active as the flood plains rise and peaks at the peak of the rains, being a moderately fecund fish. The high fecundity is complemented with peaks of GSI observed during the months of September, October, and November, which reveals spawning periods. Hence, the aforementioned attributes of the African bonytongue make it a suitable candidate for culture.
Abbreviations
H. niloticus: Heterotis niloticus
GIT: Gastrointestinal tract
N: $\quad$ Sample size
Df: $\quad$ Degree of freedom. 


\section{Data Availability}

The data used to support the findings of this study are included in the article.

\section{Ethical Approval}

Not applicable.

\section{Consent}

Not applicable.

\section{Conflicts of Interest}

The authors declare that there are no conflicts of interest regarding the publication of this study.

\section{Authors' Contributions}

Dr. M. O. A. is the principal researcher and was responsible for sample collection, analyses, and manuscript writing. Mr. F. E. A. participated in handling field and laboratory procedures. Dr. H. O. E. contributed to histological preparations and analyses of processes. All authors read and approved the manuscript.

\section{Acknowledgments}

The authors would like to thank Prof. Oniye for research methodology and guiding and the management of Edo State University, Uzairue, for the opportunity and provision of research laboratory and standard research materials.

\section{References}

[1] J. Moreau, "Exposé synoptique des donnéesbiologiquessur Heterotis niloticus (Cuvier, 1829)," Fao Fisheries Synopsis, vol. 131, p. 44, 1982.

[2] M. O. Agbugui and S. J. Oniye, "The mouth and gastro-intestinal tract of the lung fish Protopterus annectens (owen, 1839) in river niger at Agenebode, Edo State, Nigeria," Egyptian Journal of Aquatic Biology and Fisheries, vol. 23, no. 4, pp. 181-188, 2019.

[3] M. K. Mustapha, "Heterotis niloticus (Cuvier, 1829), a threatened fish species in oyun reservoir, offa, Nigeria: the need for its conservation," Asian Journal of Experimental Biological Sciences, vol. 1, no. 1-7, pp. 511-514, 2010.

[4] G. E. Odo, H. O. Nwamba, and J. E. Eyo, "Aspects of the biology of Heterotis niloticus Cuvier 1829 (osteoglossiformes: osteoglossidae) in the anambra flood river system, Nigeria," Animal Research International, vol. 6, no. 2, pp. 994-1002, 2009.

[5] R. L. Welcomme, "International introductions of inland aquatic species," FAO Fisheries Technical Paper, vol. 294, p. $318,1988$.

[6] R. Laë, "Climatic and anthropogenic effects on fish diversity and fish yields in the central delta of the Niger river," Aquatic Living Resources, vol. 8, no. 1, pp. 43-58, 1995.

[7] WHO, Vitamins and Mineral Requirements in Human Nutrition, WHO and FAO, Geneva, Switzerland, 2nd edition, 2004.

[8] WHO, Healthy Diets, WHO, Geneva, Switzerland, 2015.
[9] R. Froese and Pauly, "Identification of Heterotisniloticus," 2020, https://www.fishbase.com.

[10] K. Pandey and JP. Shukla, Fish and Fisheries: A Text Book for University Principles of Zoology, McGraw-Hill, NewYork, NY, USA, 15th edition, 2005.

[11] W. T. Reed, A. J. Burchad, J. Hopson, J. Jenness, and I. Yaro, Fish and Fisheries of Northern. Nigeria, Ministry of Agriculture, Northern Nigeria, Abuja, Nigeria, 1967.

[12] D. Paul, "Some simple methods for the assesmments of tropical fish stocks," FAO, Rome, Italy, 234, 1983.

[13] A. Ugwumba, A. Ugwumba, and V. Ebochuo, "Studies on the gonads of mormyrids of lekki lagoon, lagos, Nigeria," Nigerian Journal of Natural Products and Medicine, vol. 6, no. 1-2, pp. 28-33, 1991.

[14] G. V. Nikolsky, The Ecology of Fishes, Academy Press, London, UK, 1963.

[15] A. A. Ugwumba, O. A. Ugwumba, Food and Feeding Ecology of Fishes in Nigeria, Jodetan Ventures, Ibadan, Nigeria, 2007.

[16] S. P. Biswas, Manual of Methods in Fish Biology, The South Asian publishers Pty ltd, New Dehli, India, 1993.

[17] J. Ogari, Predator-Prey Relationship in Lake Victoria with Special Reference to Nile Perch Latesniloticus (LINNE), Marine and Fisheries Research Institute, Kisumu, Kenya, 1988.

[18] R. Froese and Pauly, "Biology of the African bony tongue," 2021, https://www.fishbase.com.

[19] A. Aditea, K. O. Winemillerb, and E. D. Fiogbe, "Ontogenetic, seasonal, and spatial variation in the diet of Heterotis niloticus (osteoglossiformes: osteoglossidae) in the Sô river and lake hlan, Benin, West Africa," Environmental Biology of Fishes, vol. 73, pp. 367-378, 2006.

[20] R. K. Buddington and J. M. Diamond, "Aristotle revisited: the function of pyloric caeca in fish," in Proceedings of the $\mathrm{Na}$ tional Academy of Sciences of the United States of America, vol. 83, pp. 8012-8014, 1986.

[21] A. A. A. Ugwumba, "Carbohydrases in the digestive tract of the African bony-tongue Heterotis niloticus (Pisces: Osteoglossidae)," Hydrobiologia, vol. 257, no. 2, pp. 95-100, 1993.

[22] A. S. Awaad, U. M. Kamal Moawad, and G. M. Tawek, "Comparative histomorphological and histochemical studies on the oesophagus of nile tilapia oreochromisniloticus and african catfish clariasgariepinus," Journal of Histology, vol. 2014, Article ID 987041, 10 pages, 2014.

[23] M. M. A. Abumandour and N. E. R. El-Bakary, "Morphological descriptions of the esophagus of the sea bream (sparus aurata, linneaus 1758)," Russian Journal of Marine Biology, vol. 44, no. 2, pp. 135-140, 2018.

[24] L. Marchetti, M. Capacchietti, M. G. Sabbieti, D. Accili, G. Materazzi, and G. Menghi, "Histology and carbohydrate histochemistry of the alimentary canal in the rainbow trout Oncorhynchus mykiss," Journal of Fish Biology, vol. 68, no. 6, pp. 1808-1821, 2006.

[25] R. R. Braga, H. Bornatowski, and J. R. S. Vitule, "Feeding ecology of fishes: an overview of worldwide publications," Reviews in Fish Biology and Fisheries, vol. 22, no. 4, pp. 915-929, 2012.

[26] S. K. Ghosh and P. Chakrabarti, "Histological and histochemical characterization on stomach of Mystus cavasius (Hamilton), Oreochromis niloticus (Linnaeus) and Gudusia chapra (Hamilton): comparative study," The Journal of Basic \& Applied Zoology, vol. 70, pp. 16-24, 2015.

[27] A. N. Alabssawy, H. M. M. Khalaf-Allah, A. A. Gafar, and A. A. Gafar, "Anatomical and histological adaptations of digestive tract in relation to food and feeding habits of 
lizardfish, Synodus variegatus (Lacepède, 1803)," The Egyptian Journal of Aquatic Research, vol. 45, no. 2, pp. 159-165, 2019.

[28] S. Takiue and H. Akiyoshi, "Light and scanning electron microscope examination of the digestive tract in peppered moray eel, gymnothoraxpictus (elopomorpha)," The Anatomical Record, vol. 296, no. 3, pp. 443-451, 2013.

[29] A. E. Hussein, M. M. K. Hassan, F. M. Mostafa, M. S. Walaa, and A. E. B. Mansour, "Food and feeding habits of some Nile river fish and their relationship to the availability of natural food resources," The Egyptian Journal of Aquatic Research, vol. 45, no. 3, pp. 273-280, 2019.

[30] M. O. Agbugui, S. J. Oniye, J. Auta, and P. T. Bolorundo, "Gastrointestinal tract of pomadasysjubelini (curvier, 1860) in the new calabar-bonny river, rivers state, Nigeria," International Journal of Engineering and Scientific Research, vol. 7, no. 10, pp. 1086-1105, 2016.

[31] C. Domeneghini, S. Arrighi, G. Radaelli, G. Bosi, and A. Veggetti, "Histochemical analysis of glycoconjugate secretion in the alimentary canal of Anguilla anguilla L," Acta Histochemica, vol. 106, no. 6, pp. 477-487, 2005.

[32] N. Lipid, "How the intestinal villi help with digestion: these little fingers do the hard work of digestion, very well health, digestive health," 2020, https://www.verywellhealth.com/ understanding-intestinal-villi- retrieved 06/04/2021.

[33] M. N. Santos, A. Canas, P. G. Lino, and C. C. Monteiro, "Length-girth relationships for 30 marine fish species," Fisheries Research, vol. 78, no. 15, pp. 368-373, 2006.

[34] S. G. Solomon, V. T. Okomoda, and S. Achodo, "Biometric relationship, food and feeding habit of Heterotis niloticus (cuvier, 1829) and Labeo coubie (ruppell, 1832) from lower river benue," Journal of Aquaculture Engineering and Fisheries Research, vol. 3, no. 1, pp. 19-27, 2016.

[35] M. O. Agbugui, S. J. Oniye, S. N. Deekae, and J. Auta, "The food and feeding habits of the sompat grunt pomadasysjubelini (cuvier, 1830) in the new calabar-bonny river, portharcourt, rivers state, Nigeria," Stem Cells, vol. 4, no. 4, pp. 55-61, 2014.

[36] K. M. Martin-Smith, "Length/weight relationships of fishes in a diverse tropical freshwater community, Sabah, Malaysia," Journal of Fish Biology, vol. 49, no. 4, pp. 731-734, 1996.

[37] R. Froese, "Cube law, condition factor and weight-length relationships: history, meta-analysis and recommendations," Journal of Applied Ichthyology, vol. 22, no. 4, pp. 241-253, 2006.

[38] R. Froese and Pauly, "The biology of Polypterusbichir," 2021, https://www.fishbase.com.

[39] G. G. Bake and S. O. E. Sadiku, "Food and feeding habits of heterotisniloticusfrom river kaduna flood plain," in Proceedings of the Annual conference of the fisheries society of Nigeria (FISON), pp. 511-514, Awka, Nigeria, 2002.

[40] A. J. Edoghotu and I. A. Hart, "Feeding habit of heterotisniloticus of kugbo creek in Niger Delta, Nigeria," Journal of Environmental Science, Toxicology and Food Technology, vol. 8, no. 10, pp. 26-29, 2014.

[41] O. A. Fagbenro, C. O. Adedire, and E. O. Ayotunde, "Haematological profile, food composition and digestive enzyme assay in the gut of the african bony-tongue fish," Heterotisniloticus, vol. 34, no. 1, pp. 97-101, 2006.

[42] M. M. S. Ward-Campbell and H. W. F. Beamish, "Morphological characteristics in relation to diet in five coexisting Thai fish species," Journal of Fish Biology, vol. 67, no. 5, pp. 1266-1279, 2005.

[43] M. O. Agbugui, F. E. Abhulimen, and M. Z. Hassan, "Distribution, morphometrics, feeding evaluation and the reproductive capacity of polypterusbichir from the river Niger at
Agenebode in Edo State Nigeria," Journal of Agriculture and Veterinary Science (IOSR-JAVS), vol. 14, no. 6, pp. 45-53, 2021a.

[44] M. O. Agbugui, F. E. Abhulimen, and O. H. Egbo, "Gross anatomy and histological features of gymnarchus niloticus (curvier, 1829) from the river Niger at Agenebode in Edo State, Nigeria," International Journal of Zoology, vol. 14, no. 6, pp. 43-55, 2021b.

[45] A. K. Saikia, S. K. S. Abujan, and S. P. Biswas, "Food and feeding habit of Channapunctatus (bloch) from the paddy field of Sivsagar district, Assam," Journal of Pharmaceutical and life sciences, vol. 1, pp. 10-15, 2012.

[46] C. T. Tiogué, D. Nguenga, J. Tekwombuo, and G. Tekou, "Morphometrics and feeding habits of the african carp Labeobarbus batesii (cyprinidae, teleostei) in the mbô floodplain rivers," Journal of Biology and Nature, vol. 3, no. 1, pp. 1-9, 2005.

[47] M. O. Agbugui, E. F. Abhulimen, A. Inobeme, and E. Olori, "Biodiversity of fish fauna in river niger at Agenebode, Edo State, Nigeria," Egyptian Journal of Aquatic Biology \& Fisheries, vol. 23, no. 4, pp. 159-166, 2019.

[48] M. O. Agbugui, S. J. Oniye, J. Auta, and F. O. Abeke, "Growth performance and feed utilization of fingerlings of Clariasgariepinus (teguels) fed processed Pauletiamonandra(kurz) seed meal," Journal of Aquatic Sciences, vol. 26, no. 1, pp. 21-27, 2011.

[49] T. Arthi, N. S. Nagaraja, and A. A. Sivakumar, "Food and feeding habits of two freshwater fishes, Ompokbimaculatus and O. malabaricus of river Amaravathy, Tamil Nadu," Journal of Life Sciences, vol. 6, no. 3, pp. 417-420, 2011.

[50] C. H. Basudha and W. Vishwanath, "Food and feeding habits of an endemic carp, Osteobramabelangeri(vol) in Manipur," Indian Journal of Fisheries, vol. 46, no. 1, pp. 71-77, 1999.

[51] M. M. Khaing and K. Y. M. Khaing, "Food and feeding habits of some freshwater fishes from ayeyarwady river, mandalay district, Myanmar," IOP Conference Series: Earth and Environmental Science, vol. 416, Article ID 012005, 2020.

[52] L. M. Rao, K. Ramaneswari, and L. V. Rao, "Food and feeding habits of channa species from east godavari district (Andhra Pradesh)," Indian Journal of Fisheries, vol. 45, no. 3, pp. 349-353, 1998.

[53] M. O. Agbugui and S. J. Oniye, "Aspects of the reproductive biology of the grunt pomadasysjubelini (curvier, 1860) in the new calabar-bonny river, rivers state, Nigeria," International Journal of Engineering and Scientific Research, vol. 7, no. 10, pp. 166-1680, 2016.

[54] M. O. Agbugui and S. N. Deekae, "Assessment of the physicochemical parameters and quality of water of the new calabarbonny river, port-harcourt, Nigeria," Cancer Biology, vol. 4, no. 1, pp. 1-9, 2013.

[55] A. P. Shoko, S. M. Limbu, H. D. J. Mrosso, A. F. Mkenda, and Y. D. Mgaya, "Effect of stocking density on growth, production and economic benefits of mixed sex nile tilapia (Oreochromis niloticus) and African sharptooth catfish (Clarias gariepinus) in polyculture and monoculture," Aquaculture Research, vol. 47, no. 1, pp. 36-50, 2014.

[56] A. P. Shoko, S. M. Limbu, H. D. J. Mrosso, and Y. D. Mgaya, "Reproductive biology of female nile tilapia oreochromisniloticus (Linnaeus) reared in monoculture and polyculture with African sharptooth catfish Clariasgariepinus (burchell)," SpringerPlus, vol. 4, p. 275, 2015.

[57] M. Holden and W. Reed, "West Africa freshwater fish," West Africa Nature Handbookpp. 27-29, Longman, Harlow, UK, 3rd edition, 1991. 
[58] G. E. Odo, H. O. Nwamba, and J. E. Eyo, "Aspects of the biology of $H$. niloticus (cuvier, 1829) (osteoglossiformis; osteoglosidae) in the anambra flood river system, Nigeria," Animal Research International, vol. 6, no. 2, pp. 994-1002, 2000 . 